Georgia State University

ScholarWorks @ Georgia State University

$1-4-2008$

\title{
Employee Choice of Flexible Spending Account Participation and Health Plan
}

Barton H. Hamilton

Washington University in St. Louis

James Marton

Georgia State university

Follow this and additional works at: https://scholarworks.gsu.edu/uwrg_workingpapers

\section{Recommended Citation}

Hamilton, Barton $\mathrm{H}$. and Marton, James, "Employee Choice of Flexible Spending Account Participation and Health Plan" (2008). UWRG Working Papers. 6.

https://scholarworks.gsu.edu/uwrg_workingpapers/6

This Article is brought to you for free and open access by the Usery Workplace Research Group at ScholarWorks @ Georgia State University. It has been accepted for inclusion in UWRG Working Papers by an authorized administrator of ScholarWorks @ Georgia State University. For more information, please contact scholarworks@gsu.edu. 
Working Paper 2008-1-4

January 2008

\section{Employee Choice of Flexible Spending Account Participation and Health Plan}

Barton H. Hamilton

Washington University in St. Louis

James Marton

Georgia State University 


\title{
Employee Choice of Flexible Spending Account Participation and Health Plan
}

\author{
Barton H. Hamilton \\ John M. Olin School of Business \\ Washington University in St. Louis \\ James Marton \\ Department of Economics \\ Andrew Young School of Policy Studies \\ Georgia State University
}

January 2008

\begin{abstract}
Despite the fact that flexible spending accounts (FSAs) are becoming an increasingly popular employer-provided health benefit, there has been very little empirical study of FSA use among employees at the individual level. This study contributes to the literature on FSAs through the use of a unique dataset that provides three years of employee-level matched benefits data. Motivated by the theoretical model of FSA choice presented in Cardon and Showalter (2001), we examine the determinants of FSA participation and contribution levels using cross sectional and random effect two part models. FSA participation and health plan choice are also modeled jointly in each year using conditional logit models. We find that, even after controlling for a number of other demographic characteristics, non-whites are less likely to participate in the FSA program, have lower contributions conditional on participation, and have a lower probability of switching to new lower cost share, higher premium plans when they were introduced. We also find evidence that choosing health plans with more expected out-of-pocket expenses is correlated with use of the FSA program.
\end{abstract}

JEL classification: I18; J33; H24

Keywords:

Flexible Spending Accounts; Health Insurance; Health Plan Choice

\footnotetext{
* corresponding author address: Department of Economics, Andrew Young School of Policy Studies, Georgia State University, P.O. Box 3992, Atlanta, GA 30302-3992; telephone: 404 - 413 - 0256; fax: 404 - 413 - 0145 ; email: marton@gsu.edu. We would like to thank J.S. Butler for his valuable advice, Arne Hole, two anonymous referees for their comments, and the human resources office at the university we studied for their help with the data. The authors retain responsibility for any errors.
}

A portion of James Marton's time spent on this research was funded through mini-grant 06-104-05 from the W.E. Upjohn Institute for Employment Research. Portions of this research were completed while Marton was a faculty member in the Martin School of Public Policy and Administration at the University of Kentucky and a post-doctoral research fellow at the Taubman Center for Public Policy at Brown University. 


\section{Introduction}

There is a small but growing literature on the use of flexible spending accounts (FSAs) to finance health (and child care) expenses with pre-tax dollars. FSA contributions are not subject to federal, state, or local income taxes. In addition, employers do not pay FICA taxes on FSA contributions. This special tax treatment of FSAs comes from a 1978 extension of Section 125 of the Internal Revenue Code, allowing it to apply to certain employee out-of-pocket expenses. Employees in firms offering a FSA can choose during open enrollment how much of their salary to contribute to their FSA. This contribution is deducted from the employee's salary on a pre-tax basis, typically in equal monthly amounts. The employee can then submit approved medical expenses for reimbursement from their FSA. One potentially negative feature of FSAs is that any unused funds are considered forfeited at the end of the year and are given back to the employer. Recently, the U.S. Department of Treasury has ruled that employers who offer FSAs under a cafeteria plan can extend the FSA plan year for an additional $21 / 2$ months, providing a "grace period" for employees to spend down their contribution.

As health care costs continue to rise, FSAs are becoming an increasingly common work related benefit offered to help employees finance out-of-pocket expenditures. According to the Kaiser Family Foundation's 2003 Employer Health Benefits Annual Survey, 83 percent of “jumbo" firms (firms with 5,000 or more employees) offered FSAs in 2003, which is an increase over the 69 percent of jumbo firms offering FSAs in 1999. The tax expenditure from cafeteria plans, to which FSA contributions can be made, is estimated to be over 23.6 billion dollars in 2005 (Joint Committee on Taxation, 2005). 
In order to determine the impact of FSAs on health care consumption and health coverage, many important questions need to be addressed. Which employees are using FSAs? Given that an employee chooses to use a FSA, what is the appropriate contribution level when faced with uncertain health care expenses and the risk of forfeiture? Because FSA participation and health plan choice are typically determined simultaneously, what factors influence this joint choice? Besides being of interest in its own right, having a better understanding of employee utilization of FSAs may also shed light on how well the "cousin" of the FSA, the Health Savings Account (HSA), performs as a component of a consumer-driven health care plan. ${ }^{2}$

There is a small literature on consumer and firm behavior with respect to FSAs (Cardon and Showalter, 2001; Cardon and Showalter, 2003; Cardon and Showalter 2007). These studies theoretically model the choice of FSA contribution level in a variety of ways. They show that when employees face a fixed health care expense, the optimal contribution is increasing in the employee's marginal tax rate, the employee's probability of the health care expense, and the size of the health care expense. In addition, when the health care expense is drawn from a continuous distribution, the optimal FSA contribution is increasing in the employee's level of risk aversion. Another study models the optimal contribution level and then uses simulations to estimate ranges of optimal contributions based on different marginal tax rates and price elasticities (Bhattacharya et al., 2002).

\footnotetext{
${ }^{2}$ Unlike an FSA, that can be used with any health plan or even in the absence of a health plan, an HSA is a specific component of a "consumer-driven" health plan. Such a plan typically offers a high deductible along with a pre-funded HSA to help cover the out-of-pocket expenses incurred before exceeding the deductible. Unlike an FSA, HSA balances can be rolled over from one year to the next, subject to some limits. Despite these differences, both the FSA and the HSA provide incentives for consumers to be more cost conscious and both require some sort of reimbursement procedure. For more discussion see Cardon and Showalter (2007).
} 
Because of the difficulty associated with obtaining consumer-level data on FSA use, the empirical literature on FSAs has lagged behind the theoretical literature. Cardon and Showalter (2001) provide perhaps the first empirical study that analyzes consumerlevel data on FSAs. They estimate FSA participation regressions using a cross-section of 1996 calendar year data from a medium sized insurance company. The regressions suggest that age and family size increase FSA participation at a decreasing rate. In addition, women, state income tax payers, and higher income individuals are more likely to participate in a FSA program. Contribution levels, conditional on participation, also increase with income, and are higher for married individuals and those with larger families.

Another recent study uses data from the cross-sectional 1993 Robert Wood Johnson Employer Health Insurance Survey (EHIS) to examine the relationship between employee FSA use and the level of cost sharing associated with the employee's insurance plan (Jack et al., 2006). When health insurance is offered by employers in conjunction with a FSA, their results suggest that the coinsurance rate associated with the health insurance plan is higher. They claim the resulting increase in out-of-pocket spending may be efficiency enhancing, as it may potentially help offset the distortionary effect of the tax subsidy given to employer-provided health insurance premiums.

Our paper extends the empirical literature on FSA use by taking advantage of a unique data set consisting of three recent years of matched human resources data for employees of a large public university in the southeast. ${ }^{3}$ The dataset provides detailed information (e.g., prices, deductibles) on the set of health insurance and FSA options available to workers at this employer in each year. This type of detailed plan information

\footnotetext{
${ }^{3}$ Examples of other papers that utilize human resources data from a single firm to examine health benefit choices include Cutler and Reber (1998) and Parente et al. (2004).
} 
is often unavailable or incomplete in large scale random population surveys. In addition, we have other explanatory variables such as race and job tenure that have not been previously analyzed in the literature.

Using the theoretical model of consumer FSA choice presented in Cardon and Showalter (2001) as our motivation, we estimate two part models of participation and contribution levels to investigate the impact of demographic and financial characteristics on these choices. In addition, we recognize that in each year the employee is faced with a number of health benefit "bundles" that consist of the joint choice of an insurance plan and whether or not to participate in the FSA program. ${ }^{4}$ Consequently, we estimate a conditional logit model that formalizes the idea that insurance plan choice and the choice to participate in the FSA program are typically made simultaneously. Finally, we use a multinomial logit (MNL) model to examine employee sorting into new plans with lower deductibles that were initially offered in year two of our panel to investigate the relationship between employee characteristics and cost sharing.

As predicted by the theoretical model, we find that FSA participation is positively correlated with employee marginal tax rates, proxies for health type such as being a female or older worker, and a proxy for the amount of health care expenses (being married). Choice of health plans with more cost sharing is also correlated with increased FSA participation. FSA contribution levels increase with income, age, and for married employees. A notable finding is that non-whites are less likely to participate in the FSA program, and make smaller contributions conditional on participation, even after controlling for other factors such as income. When FSA participation and health plan

\footnotetext{
${ }^{4}$ For example, in 2001, employees can choose between an HMO, a PPO, or no coverage. By combining these three health plan options with the yes or no FSA participation decision each employee has six health benefit "bundles" to choose from in 2001.
} 
choice is viewed as a joint decision, age, salary, and marital status are correlated with the choice of a "bundle" that includes a positive FSA contribution. Finally, our analysis of employee sorting across new health plans suggests that proxies for health type (age, gender), a proxy for the amount of health expenses (marital status), income, and previous plan choice have a statistically significant association with the choice to switch to one of the new lower cost share / risk, higher premium plans. Even after controlling for a number of other factors, non-whites have a lower probability of switching to one of these new lower risk plans.

\section{Theoretical Model of Cardon and Showalter (2001)}

In this section, we briefly describe a theoretical model of FSA choice presented in Cardon and Showalter (2001), which provides motivation for the empirical models we estimate in this paper. Assume that with probability $q$ an employee (or their family) faces a potential loss of $\$ L$ due to health care expenses. This loss may be a function of a variety of measurable characteristics of the employee or their family, including their level of insurance coverage and family size. The probability of incurring a loss due to health care expenses is also a function of a variety of measurable characteristics including age, gender, race, and education level. Let $I$ be the employee's pre-tax income, $\tau$ be their marginal tax rate, and $F$ be their choice of FSA contribution level, then the employee's state contingent non-health expenditures are given by $M$ :

\begin{tabular}{|l|l|l|}
\hline State of the World & Probability & Non-health Expenditures \\
\hline Loss & $q$ & $M_{\text {loss }}=(I-F) *(1-\tau)-L+F$ \\
\hline No Loss & $(1-q)$ & $M_{\text {no loss }}=(I-F) *(1-\tau)$ \\
\hline
\end{tabular}


Given these state contingent budget constraints, the employee chooses $F$ to maximize their expected utility:

$$
\text { choose F to maximize } E U(F)=q * U\left(M_{\text {loss }}\right)+(1-q) * U\left(M_{\text {no loss }}\right)
$$

Allowing employees to choose their FSA contribution level (as opposed to offering a fixed contribution level) is supported in theory by models of benefit provision that assume imperfect worker sorting across firms (Dranove et al., 2000; Gruber and McKnight, 2003; Levy, 1998). This imperfect sorting implies heterogeneity in tastes for insurance and FSA contributions. As in Cardon and Showalter (2001), utility is assumed to exhibit decreasing marginal utility, risk aversion, and decreasing absolute risk aversion (DARA). ${ }^{5}$ Because the optimization problem is globally concave in $F$, there is a unique optimal FSA contribution level, $F^{*}$. Focusing on an initial interior solution $\left(0<F^{*}<L\right)$, the comparative static results can be summarized as follows:

$$
\begin{array}{ll}
\text { - } \operatorname{as} q \uparrow, F^{*} \uparrow & \text { - } a s I \uparrow, F^{*} \downarrow \\
\text { - } \operatorname{as} L \uparrow, F^{*} \uparrow & \text { - } a s \tau \uparrow, F^{*} \uparrow
\end{array}
$$

In addition, Cardon and Showalter (2001) present a simulation that predicts that increasing levels of risk aversion lead to greater FSA contributions.

The intuition behind these results is given through a comparison of the expected marginal benefit of the FSA in the loss state and the expected marginal cost of the FSA in the no loss state. For example, if the loss due to illness $(L)$ increases, the expected marginal benefit of the FSA in the loss state increases, while the expected marginal cost in the no loss state stays the same. This implies an increase in the optimal FSA

\footnotetext{
${ }^{5}$ These assumptions imply $U^{\prime}>0, U^{\prime \prime}<0$, and $U^{\prime \prime \prime}>\left(U^{\prime \prime}\right)^{2} / \mathrm{U}^{\prime}>0$. The DARA assumption implies that as wealth increases, an individual is willing to bear more risk. It is made to sign otherwise ambiguous comparative static results. See Cardon and Showalter (2001) for more discussion.
} 
contribution $\left(F^{*}\right)$. For a more complete description of the comparative static results, see Cardon and Showalter (2001).

In order to bring the theoretical model to the data, employee income must be measured and their marginal tax rate estimated. In addition, proxies for the probability of a health loss, the dollar value of a health loss, and employee risk aversion must be found. As is discussed in more detail below, the human resources data used in this paper includes employee income $(I)$. Using employee demographic characteristics, their marginal tax rate $(\tau)$ is estimated using the NBER's TAXSIM tax calculator. While we have no direct measures of health status or health claims, employee characteristics such as age, gender, race, and education level (as measured by a faculty vs. staff indicator) are used as proxies for the probability of having a health care expense $(q)$ or health type. Holding these characteristics constant, we use type of insurance and marital status as proxies for the size of the health care expense $(L)$. Unfortunately, as is the case for most data sets, direct measures of employee risk aversion are not available. However, it may be the case that more risk averse employees are less likely to leave the university, after controlling for age and income (which presumably reflects the worker's productivity). Consequently, we include job tenure as a proxy for the level of employee risk aversion, although we recognize this variable could reflect other factors as well.

\section{Study Setting}

Individuals in the data are all full-time employees of a public university in the southeast during at least one of the years 2001, 2002, and 2003. This university has a workforce that includes approximately 12,000 full-time employees in a given year, of which roughly 18 percent are faculty and the rest are considered staff. In each of the three years, the university offered a FSA to their employees with a contribution minimum 
of $\$ 250$ and a contribution maximum of $\$ 4,000$. The university also offered a variety of health plans for employees to choose from. Premiums vary by plan and the university covers most of the premium for the employee and a smaller percentage of the premium for any dependents. ${ }^{6}$ Table 1 gives both the total monthly premium for single coverage under each plan and the employee's share.

In 2001, employees could choose between a traditional health maintenance organization (HMO) and a preferred provider organization (PPO). The HMO network consists mainly of university providers and involves very little out-of-pocket expenses for enrollees. The PPO has a wider provider network that includes non-university physicians and requires more out-of-pocket cost sharing (due to higher coinsurance rates and deductibles). Table 1 illustrates the fact that the HMO premium is always the lowest among all plans offered by the university.

In 2002, two new plans were offered, a PPO High option and an exclusive provider organization (EPO) plan. The PPO High option has a lower deductible than the PPO and a higher premium. The EPO is similar to the HMO in terms of minimal cost sharing, but offers a wider provider network. This makes the EPO premium the highest among all of the plans. In 2003, a consumer-driven plan was offered for the first time. The consumer-driven plan offers a $\$ 500$ personal care account, a $\$ 1,000$ deductible, and then a 20 percent coinsurance rate that becomes active once the deductible has been met. The plan also covers preventative care with a $\$ 15$ co-payment. None of the employees in our sample in 2003 selected the consumer-driven plan. ${ }^{7}$

\footnotetext{
${ }^{6}$ For a formal treatment of why an employee's level of contribution to employer-provided health insurance premiums is important for the choice of health plan see Gruber and McKnight (2003).

${ }^{7}$ In the benefits information provided by the employer, the possibility of rolling over un-used funds from the personal care account into the next plan year is not mentioned. However, starting in 2004 this is a possibility, subject to some limits.
} 


\section{Data and Methods}

The analysis is focused on the full-time university employees between the ages of 25 and 64 with no missing data that worked at least one year during the three year period 2001-2003. Medicare and other health benefits are available to employees aged 65 and older. All of the data on these employees was provided by the human resources department at the university. Table 2 provides the descriptive statistics for the sample.

Table 2 illustrates that the average age among employees in each year is about 45 years old, between 55 percent and 58 percent of employees are female in each year, and there are slightly more married employees than single. In each year between 15 percent and 16 percent of employees are non-white and the average job tenure is approximately 11 years. FSA participation in the sample is growing over time, as is the average FSA contribution. ${ }^{8}$ In 2003, the average FSA contribution for all employees is $\$ 159$ dollars. Among FSA participants, the average contribution in 2003 is $\$ 1,257$. Figure 1 shows that most of these contributions are $\$ 1,500$ or less. The average salary is increasing between 2001 and 2003 .

HMO enrollment is falling slightly over time. The introduction of the PPO High option and the EPO seemed to draw employees away from the PPO towards these plans with less cost sharing and higher premiums, but equivalent (broad) provider networks. ${ }^{9}$

It is also interesting to note that the introduction of these additional insurance options did not result in a statistically significant change in the percent of employees with no insurance coverage from the university. Finally, we estimate each employee's marginal

\footnotetext{
${ }^{8}$ The employer has a separate FSA program for day care expenses. We ignore contributions to the day care FSA program because in each year less than 3 percent of employees participate. This is much smaller than the double digit participation rate in the health care FSA program in each year. Therefore, day care contributions are completely excluded from this analysis.

${ }^{9}$ To be more specific, 6.57 percent of 2001 employees switched to the newly introduced PPO High or EPO options in 2003. Of these plan changers, 20 percent (72 percent) were enrolled in an HMO (PPO) in 2001. This implies 8 percent of these plan changers were uninsured through this employer in 2001.
} 
tax rate in each year using TAXSIM Version $6.4 .^{10}$ The inputs we provided are the tax year, the employee's salary, their marital status, and their state of residence. The marginal tax rate estimates include federal, state, and FICA rates. In 2003, the average marginal tax rate is 37 percent.

As in Cardon and Showalter (2001), we estimate a standard two part model of FSA participation and contribution levels. ${ }^{11}$ Assume that the "propensity" of employee $i$ to participate in the FSA program in year $t$ is given by:

$$
y_{i t}^{*}=X_{i t} \beta_{1}+\varepsilon_{1 i t} \text {. }
$$

The binary outcome for whether or not employee $i$ participates is given by:

$$
F S A_{-} \text {participation }_{i t}=\left[\begin{array}{lll}
1 & \text { if } & y_{i t}^{*}>0 \\
0 & \text { if } & y_{i t}^{*} \leq 0
\end{array}\right] \text {. }
$$

The contribution equation is estimated for those with positive contributions using OLS with the dependent variable equal to the natural log of the FSA contribution level:

$$
\log \left(F_{S} A_{-} \text {contribution }_{i t}\right) \mid\left(F_{S} A_{-} \text {participation }_{i t}=1\right)=X_{i t} \beta_{2}+\varepsilon_{2 i t} \text {. }
$$

The covariate vector $\left(X_{i t}\right)$ consists of those variables described in Table 2.

We first estimate this two part model separately by year to determine whether the impact of the covariates on FSA participation and contributions remain stable over the three year period, particularly after the introduction of the new health plan options in 2002. However, employee choices were relatively persistent over time. Approximately 9 percent of employees working full time in 2001 and 2003 changed their FSA contribution level between those years, while about 7 percent switched to one of the new health plans in 2002 or 2003. To allow for individual-level correlation over time, we introduce employee-level random effects $\theta_{1 i}$ and $\theta_{2 i}$ :

\footnotetext{
${ }^{10}$ See Feenburg and Coutts (1993) for an introduction to the TAXSIM model.

${ }^{11}$ See Duan et al. (1984) for a discussion of the two part model.
} 


$$
\begin{gathered}
y_{i t}^{*}=X_{i t} \beta_{1}+\theta_{1 i}+u_{1 i t} \\
\log (F S \text { FA_contribution }) \mid\left(\text { FSA_participation }_{i t}=1\right)=X_{i t} \beta_{2}+\theta_{2 i}+u_{2 i t} .
\end{gathered}
$$

Because there is reason to believe that the FSA participation decision is made simultaneously with the choice of health plan, we also estimate a McFadden conditional logit model for each year to predict the joint decision of FSA participation and health plan choice. This modeling approach has been used extensively in the literature on health plan choice, with one recent example being Parente et al. (2004). ${ }^{12}$ In these models, researchers typically condition health plan choice on the tax adjusted premium each employee faces for each plan. These tax adjusted premiums are a function of the nonadjusted premiums that each employee faces and the employee's individual marginal tax rate. Therefore, in the conditional logit model, employee marginal tax rates enter through the tax adjusted premiums rather than directly on the right hand side.

Rather than restricting our attention to health plans alone, we consider the joint choice of health plan and FSA participation. Assume that, in each year, an employee chooses between B health benefit "bundles." Let $y_{i b}=1$ if employee $i$ chooses bundle $b$ and $y_{i b}{ }^{\prime}=0$ for $b^{\prime} \neq b$. In 2001, employees have six choices $(\mathrm{B}=6)$ and in 2002 and 2003 they have eight ( $\mathrm{B}=8$ due to the introduction of new plans):

\begin{tabular}{|l|l|l|}
\hline Bundle & $\mathbf{2 0 0 1}$ & $\mathbf{2 0 0 2}$ and 2003 \\
\hline 1 & No FSA, No Health Plan & No FSA, No Health Plan \\
\hline 2 & No FSA, HMO & No FSA, HMO \\
\hline 3 & No FSA, PPO & No FSA, PPO \\
\hline
\end{tabular}

12 Other studies include Feldman et al. (1989), Dowd and Feldman (1994 / 1995), and Harris, Schultz, and Feldman (2002). 


\begin{tabular}{|l|l|l|}
\hline 4 & & No FSA, PPO High / EPO \\
\hline 5 & FSA, No Health Plan & FSA, No Health Plan \\
\hline 6 & FSA, HMO & FSA, HMO \\
\hline 7 & FSA, PPO & FSA, PPO \\
\hline 8 & & FSA, PPO High / EPO \\
\hline
\end{tabular}

Each employee is assumed to choose the bundle that maximizes their utility, where the utility of a health "bundle," $U_{i b}$ is given by:

$$
U_{i b}=\alpha_{b}+W_{i} \gamma_{b}+M_{i b} \mu+v_{i b},
$$

where $\alpha_{b}$ is a bundle-specific constant capturing the average contribution to utility, and $W_{i}$ is a vector of employee characteristics, such as gender and race, which do not vary across bundles. The impact of employee characteristics on utility is allowed to vary across bundles by allowing for a bundle-specific parameter vector, $\gamma_{b}$. We can then estimate the effect of each employee characteristic on the probability of choosing each bundle. $^{13}$

Employee choice will also be a function of a vector of bundle-specific personal attributes, $M_{i b}$, that vary by bundle and by employee. The two bundle-specific personal attributes we consider are the bundle's "tax adjusted" out-of-pocket insurance premium and the bundle's FSA tax savings. The bundle's tax adjusted out-of-pocket premium is defined to be the premium paid by the employee for the health plan in the bundle, adjusting for the fact that employees purchase health insurance with pre-tax dollars. The bundle's FSA tax savings are defined to be how much tax savings the employee would

\footnotetext{
${ }^{13}$ Note that at this employer workers may sign up for the health care FSA even if they are not signed up for one of the health plans the employer sponsors. Bundle 5 above represents this choice. In may not be the case in every firm that employees are allowed to sign up for the FSA program without also participating in an employer-sponsored health plan.
} 
receive from a $\$ 1,000$ pre-tax FSA contribution. This is positive for the bundles that include FSA participation and zero for those that do not. Notice that these attributes reflect both the marginal tax rate of the employee and the contents of the bundle, so are neither strictly employee-specific nor strictly bundle-specific. Finally, the random error, $v_{i b}$, represents unobserved, employee-specific aspects of utility from bundle $\mathrm{b}$, which are assumed to be independently and identically distributed with an extreme value distribution.

Denote by $P_{i b}$ the probability that employee $i$ chooses bundle $b$. The conditional logit model for each year will estimate the effects of $W_{i}$ and $M_{i b}$ on the B choice probabilities for each employee i, each given as:

$$
P_{i b}=\exp \left(\alpha_{b}+\gamma_{b}^{\prime} W_{i}+\mu^{\prime} M_{i b}\right) / \sum_{k=1}^{B} \exp \left(\alpha_{k}+\gamma_{k}^{\prime} W_{i}+\mu^{\prime} M_{i k}\right)
$$

Although Feldman et al. (1989) suggests that employees should be grouped together by similarity of choice sets and choice models should be estimated separately for each group, we follow Parente et al. (2004) and combine employees with single and family coverage for our primary results. Because we have no information about spousal insurance options if the spouse works outside the university, we assess the robustness of our results by re-estimating each model separately for single employees. Details of these results are presented in the appendix.

Finally, we examine how the introduction of the lower cost share, higher premium PPO High and EPO health plans impacted employee choice of bundles between 2001 and 2003 using a multinomial logit (MNL) model. In 2003, employees have three choices: 
- They can continue to choose one of the bundles that was available in 2001 $($ stayer $-\mathrm{S}) .{ }^{14}$

- They can switch to one of the new plans with no FSA contribution (bundle 4 (no FSA contribution, PPO High or EPO health plan) - B4).

- They can switch to one of the new plans with an FSA contribution (bundle 8 (FSA contribution, PPO High or EPO health plan) - B8).

Denote the utility associated with each of these $j=3$ choices by $U_{S}, U_{B 4}$, and $U_{B 8}$, respectively. The utility of choice $j$ is a function of the individual characteristics shown in Table 2, $X_{i}$, and indicators for the health bundle chosen in 2001, $B_{i 2001}$ :

$$
U_{i j}=X_{i} \beta_{j}+B_{i 2001} \lambda_{j}+e_{i j} .
$$

This specification captures the idea that employees with a strong preference for their existing health plan, perhaps because of its balance of out-of-pocket cost sharing and premium or due to their relationship with a particular physician or hospital, will derive relatively less utility from the introduction of the new plans. It may also be the case that particular groups of employees, such as those with high salaries, will find one of the new options particularly attractive. We estimate the switching probabilities implied by the utility specification in (6) using MNL.

Analysis of sorting into these new health plans is interesting for a variety reasons. First, we are able to directly investigate whether the introduction of new health insurance options affects the FSA participation decision. Because the new plans have lower deductibles and higher premiums, we might expect employees choosing them to be less likely to participate in the FSA program. Second, the introduction of the new plans is a

\footnotetext{
${ }^{14}$ We could decompose state $\mathrm{S}$ into the 6 individual bundles that were available in both 2001 and 2003. However, our focus is on the factors influencing the switch to one of the two new options in 2003, so we chose to categorize the 6 options existing from 2001 into state S.
} 
"quasi-experiment" that allows us to identify determinants of employee preferences over different levels of cost sharing / risk. The new plans are identical to the original PPO option in terms of having broad provider networks, but they offer less up front cost sharing (less risk) in return for higher premiums. Consequently, employees switching from the PPO to the PPO High (or the EPO) are revealing their preferences for lower cost sharing (less risk) versus higher premiums for the same set of providers.

\section{Results}

\section{Two Part Models of FSA Participation and Contribution Levels}

Table 3 presents the results of our two part models estimated on the full sample in each year (columns 1-3), along with the random effects results for the pooled full sample (column 4). To assess the robustness of the results, we also present the random effects results for the singles sample in Column 5. Like Cardon and Showalter (2001), we find that income, proxies for the probability of a health care expense (gender and age), and proxies for the size of a health care expense (marital status) have a statistically significant impact on the FSA participation decision. In addition, these same proxies for the size of a health care expense have a statistically significant impact on FSA contribution amounts. Finally, we include employee marginal tax rates in our models and find that, as one would expect, a higher marginal tax rate is strongly associated with an increased probability of FSA participation. This is similar to the finding in Cardon and Showalter (2001) that living in a state with a state income tax is associated with an increased probability of FSA participation.

The coefficient estimates for $\log$ (salary) show that higher income employees are more likely to participate in the FSA program. Moreover, conditional on participation, we estimate significant and positive income elasticities for contributions ranging from 
0.19 to 0.27 , implying that participants with 10 percent higher incomes contribute 1.9 percent -2.7 percent more to their FSA. Higher salary individuals may have a higher optimal level of healthcare expenditure if healthcare is a normal good. Conversely, the theoretical model summarized in Section II suggests that the income effect may be limited if higher income individuals are willing to bear more risk. In this case, higher income individuals will reduce their contribution to the FSA. Overall, it appears that the income effect outweighs the risk-bearing effect, even after controlling for the marginal tax rate.

As discussed above, female and older workers may face a greater probability $(q)$ of health expenditures; our coefficient estimates predict that being female is associated with increases in FSA participation by 2 or 3 percentage points, but no significant increase in FSA contributions. Our models also predict that aging is associated with increased participation and an age elasticity of demand for FSA contributions of .56 in the pooled contribution regression in Table 3 (column 4). Married individuals may use their FSA accounts to cover the health expenditures of spouses and children, thus increasing the size of potential health expenditures $(L)$. Our coefficient estimates predict that being married is associated with a 3 or 4 percentage point increase in the probability of FSA participation and is also associated with an increase in the employee's FSA contribution. Finally, the FSA program appears to have become slightly more popular over time, given that the fraction of workers contributing in 2003 was 1.31 percentage points higher than in 2001.

The most surprising result in Table 3 is the significantly reduced likelihood of making an FSA contribution by non-white employees. The estimated coefficients in the participation regressions suggest that being non-white is associated with a 3 or 4 
percentage point reduction in FSA participation relative to whites. In addition, nonwhites make smaller FSA contributions conditional on participation. These results cannot be simply explained by racial income differences among employees, since (log)income is included in the regressions. One possible explanation for our findings is that the spouses of non-white employees may have lower paying jobs, leaving less disposable income that can be allocated to their FSA and lowering the tax subsidy associated with their contribution. To address this issue, we re-estimated the model excluding married employees. Column 5 of Table 3 reports these results for the full three year panel. ${ }^{15}$ Restricting attention to singles does not change the result that non-whites are less likely to participate in the FSA program, suggesting that unobserved differences in household income are unlikely to be a primary cause of this difference in take-up rates. However, the racial difference in contribution levels is no longer statistically significant in the singles sample, which may suggest that the spouses of non-white employees have lower income jobs than the spouses of white employees.

We performed a number of additional specification checks to assess the robustness of the results in Table 3. First, we replaced $\log$ (salary) with a quadratic in salary (and did the same for $\log ($ age $)$ and $\log ($ tenure $)$ ) and found that this alternative functional form did not affect the coefficient estimates of the other variables in the two part models. Second, we re-estimated the contribution regressions as Tobit models to recognize the fact that FSA contributions have an upper bound. The results were virtually identical to those presented in Table 3, likely because few employees choose the maximum FSA contribution. Third, other than the difference in the relationship between race and contribution levels, comparison of columns (4) and (5) from Table 3 show that

\footnotetext{
${ }^{15}$ The results from the singles samples for each year are reported in Appendix Table A3.
} 
the results for the singles sample are generally consistent with the results for the full sample. This gives us confidence that the full sample results in Table 3 are not driven by omitted variables relating to the families of the employees. ${ }^{16}$

We next examine the relationship between health insurance plan choice and FSA behavior, since health plan cost sharing rules are a determinant of the size of potential health care expenses $(L)$. We re-estimate the two part models from Table 3, including indicators for the type of insurance policy selected in the given year, where the excluded category is no coverage through this employer. The results in Table 4 suggest that insurance plan choice has a statistically significant impact on the FSA participation decision. The magnitude of the effect increases with the amount of cost sharing associated with each health plan, as is suggested by Jack et al. (2005). For example, the coefficients in the 2002 model suggest that relative to an employee with no health coverage, those enrolled in the HMO (PPO, PPO High, EPO) are $6(10,15,21)$ percentage points more likely to participate in the FSA program.

Despite this finding, insurance plan choice does not appear to have a significant impact on FSA contribution levels. The health plan indicators are generally not statistically significant in the contribution regressions. Table A4 presents estimates of the same models restricted to the singles sample. As in Table 3, the results are similar, though smaller in magnitude for the health plan variables. We emphasize that our estimates are not necessarily causal, since FSA participation and health plan choice may be simultaneously determined. This relationship motivates our use of conditional logit models to explicitly examine the joint choice of insurance plan and FSA participation.

\footnotetext{
${ }^{16}$ The lack of data on families is a common problem for studies using employee data obtained from a firm's human resource department. This limitation is offset by the availability of detailed information on the choices of health and retirement plans provided to employees by the firm. See Cardon and Showalter (2001), Cutler and Reber (1998), and Madrian and Shea (2001) for examples of similar datasets.
} 


\section{Conditional Logit Models for "Bundles" of Health Benefits}

Due to the likelihood that decisions regarding health plan choice and FSA participation are made jointly, we turn to the results of the conditional logit models of health bundle choice. Rather than present the estimates for all three years of our data, we focus on the estimates for the full sample in 2001, shown in the first column of Table 5, when the only health plans offered by the employer were the HMO and PPO, and on the results for the full sample in 2003, shown in the second column of the table, when the PPO High and EPO options were also available. ${ }^{17}$ In addition, we provide estimates of the same models restricted to the singles sample in 2001 and 2003 in the third and fourth columns. At the bottom of each column, the overall probability associated with each bundle is given.

Prior to estimating the conditional logit model, we subtracted the sample mean values of the continuous independent variables, $\log ($ age $), \log ($ tenure $)$, and $\log$ (salary) so that bundle-specific constants $\left(\alpha_{b}\right)$ can be interpreted as reflecting the preferences of the average employee. The first seven rows of Table 5 present the estimates of these bundlespecific constants. Not surprisingly, given the "market shares" for each bundle at the bottom of the table, the average employee in the full sample has the strongest preference for the (HMO, No FSA) bundle, and the least preference for the (NO Cov, FSA) and (PPO High, FSA) bundles in 2001 and 2003, respectively. However, examination of the impact of employee characteristics on bundle choice suggests workers that are likely to have greater health needs or who have greater disposable income have greater preference for bundles that include the PPO plan or a contribution to the FSA. For example, in the full sample in 2001 an increase in (log) age is associated with a statistically significant

\footnotetext{
${ }^{17}$ The 2002 results were quite similar to those presented in the paper for 2003, and are available from the authors upon request.
} 
decline in the probability of enrolling in the HMO without an FSA, and a statistically significant increase for the (PPO, No FSA) option. In the case of salary, higher salaried workers in the full sample in 2003 substitute away from the no coverage, no FSA bundle in favor of bundles that incorporate FSAs. Note that this does not simply reflect the greater tax subsidy associated with the FSA for higher income workers, since we also control for the FSA tax savings in the model.

The marginal effects associated with the coefficient estimates for marriage suggest the influence of outside insurance options. In both years in the full sample, being married results in a 17 - 19 percentage point drop in the chances an employee chooses the (HMO, No FSA) bundle and a corresponding 18-22 percentage point increase in the probability of choosing the bundle with no insurance coverage and no FSA participation. It is plausible that married workers may be obtaining coverage through their spouse's employer. The conditional logit results for the singles sample presented in columns 3 and 4 are generally consistent with those for the full sample.

As is the case with the two part models from Table 3, the most surprising results in Table 5 concern the impact of race. Non-whites are more likely to choose the HMO plan without an FSA contribution. This finding primarily reflects the substitution by nonwhites away from no insurance coverage (and no FSA contribution) toward the HMO. The (HMO, No FSA) bundle has the lowest out-of-pocket cost and premiums among all options that involve some insurance coverage in each year. Consequently, the estimated preferences for non-whites may reflect tighter family budget constraints faced by this group.

The estimates in the bottom rows of the table suggest that greater tax savings is associated with an increase in the probability of choosing a bundle that includes an FSA 
contribution, all else equal. A somewhat puzzling result is the finding that bundles with higher priced health plans are more likely to be chosen. It may be the case that our specification does not adequately control for non-price features of the plan, such as the quality and breadth of providers, which are positively correlated with price.

In order to assess whether or not we could drop one of the bundles without violating the independence of irrelevant alternatives (IIA) assumption, Hausman tests were performed by dropping each alternative individually. The tests generally did not support the IIA assumption, which implies that our results may be dependent on the particular sets of bundles offered by this employer. This issue is a common one in the literature. For example, in the study of health plan choice modeled with conditional logit models presented in Parente et al. (2004), the IIA assumption also fails to hold.

\section{MNL Models of Bundle Switching and Preferences for Less Cost Sharing}

As mentioned above, the purpose of this final piece of analysis is to determine the impact of the introduction of two new health plans (PPO High and EPO) on employee choice of health benefit bundles. Both the PPO High and the EPO health plans offer similar broad provider networks as the PPO, but lower cost sharing (less risk). Due to the lower cost sharing, these new plans charge higher monthly premiums. The results of a MNL model examining the employee's decision to switch to one of the new options between 2001 and 2003 are presented in Table 6. Again the first two columns represent the results for the full sample and the last two represent the results for the singles sample. Employees may choose not to purchase one of the new health plans (S), purchase one of the new plans without an FSA contribution (B4), or purchase one of the new plans with an FSA contribution (B8). Overall, 7 percent of employees in the full sample switched to 
one of the new plans: 5 percent switched to a new plan without an FSA contribution; and 2 percent switched to a new plan with an FSA contribution.

Proxies for health type such as being female and increasing age are associated with an increased probability of switching to one of new plans with less risk and higher premiums in the full sample. Higher paid workers are more likely to choose less cost sharing, but the coefficients on the employee's marginal tax rate are not statistically significant. Therefore, higher income individuals appear to prefer more certainty in their health care costs, as do married employees. After controlling for other employee characteristics, the coefficients for non-white employees in the full sample suggest that they are 1 percentage point less likely to switch to one of the new plans with less cost sharing / risk. This may again reflect tighter family budget constraints as a result of unobserved spousal income, so that it is not possible to take on the additional premium associated with one of the new plans.

The coefficients on the 2001 bundle choices of the employees indicate a variety of notable findings. First, for many employees switching bundles, the choices of health plan and FSA participation appear to be separable. For example, switchers choosing a bundle with a FSA in 2001 continue to participate in the FSA in 2003, despite the lower deductibles of the new plans. Only in the case of workers choosing the (PPO, No FSA) bundle in 2001 do we observe increased take-up of the FSA option when they switch to the new lower deductible plans. In particular, for the full sample the coefficient estimates imply that employees originally enrolled in the PPO without an FSA are 19 percentage points more likely to switch to a new plan without an FSA and 2 percentage points more likely to switch to a new plan with an FSA. This implies some of the employees enrolled in the PPO in 2001 may have preferred a plan with less cost sharing / risk and higher 
premiums. Second, employees without insurance coverage in 2001 are more likely to choose one of the new plans available in 2003 (without changing the FSA participation decision). These employees may have turned down coverage in 2001 because there was not a plan being offered with the combination of cost sharing, provider network, and premiums they were willing to consume, rather than simply not being able to afford health insurance.

Overall, the results for the full sample suggest that higher income employees were able to "purchase" less cost sharing in their health care expenditures by choosing the new plans. Lower income employees and non-whites were less likely to take advantage of the new options, perhaps because of the higher premiums associated with them. ${ }^{18}$

\section{Conclusion}

Despite the fact that flexible spending accounts are becoming an increasingly popular employer-provided health benefit, there has been very little empirical study of FSA use among employees at the individual level. This study contributes to the literature on FSAs through the use of a unique dataset that provides three years of employee-level matched benefits data. In fact, our study is the first to jointly analyze health plan choice and FSA participation decisions with such data. Using the theoretical model of Cardon and Showalter (2001) as motivation, we find that overall FSA participation and contributions are growing over the three years analyzed, although participants remain a relatively small minority of employees.

\footnotetext{
${ }^{18}$ To assess the sensitivity of these findings to potential omitted spousal variables, we re-estimated the model for the singles sample. Columns (3) and (4) of Table 6 show that the coefficients are of similar sign, though somewhat smaller in magnitude when compared to the full sample results. Single individuals choosing the (No Insurance, No FSA), (HMO, FSA), or (No Insurance, FSA) bundles in 2001 were highly unlikely to switch to one of the new plans by 2003, so the coefficients for these categories were restricted to zero in the estimation procedure.
} 
Our two part models of FSA participation and contribution levels support the initial findings in the literature that income and marital status / family size have a statistically significant effect on both FSA participation and contribution levels. As in the previous literature, we find that age, gender, and marginal tax rates are significant predictors of FSA participation. We also find the surprising result that, even after controlling for income, marginal tax rate, faculty status, age, and marital status, nonwhites are less likely to participate in the FSA program and lower contributions conditional on participation. A recent study of participation in employee retirement programs shows that non-whites are less likely to make voluntary contributions to $401(\mathrm{k})$ plans (Madrian and Shea (2001)). As in the case of retirement plans, conversion of the FSA to an "opt-out" benefit may particularly increase the participation of non-white employees.

The two part models with controls for insurance policy choice suggest that FSA participation is correlated with the choice of insurance plans with higher employee outof-pocket expenses. In a sense, these employees are creating their own "consumerdriven" plan. Perhaps they are willing to accept higher cost sharing in return for more provider flexibility in part because they know they can use the FSA program to help offset these out-of-pocket expenses. These same employees may not be willing to sign up for the consumer-driven plan because this arrangement still provides lower cost sharing than the consumer-driven option.

The FSA participation and health plan choice decisions are modeled jointly in each year using conditional logit models. Due to the lack of FSA data available, this approach is also new to the literature. Across all years, the tax adjusted premium and the level of FSA tax savings are statistically significant. Age, salary, and marital status seem 
to be the employee characteristics significantly correlated with movement into bundles that include FSA use, with the strongest effects coming from age and salary. Being nonwhite in each year is statistically significantly correlated with a movement into the (HMO, No FSA) bundle. These results further support the finding that non-whites seem to make different decisions with respect to health benefits than whites, even after controlling for a number of other demographic characteristics. One interpretation is that due to tighter family budget constraints, non-whites seek health coverage with the combination of lowest out-of-pocket expense and lowest premium. Further investigation is needed to determine the factors influencing racial differences in the choice of the health care benefit "bundle."

Finally, our analysis of employee sorting across new health plans suggests that proxies for health type (age, gender), a proxy for the size of potential health expenses (marital status), income, and previous plan choice have a statistically significant association with the choice to switch to one of the new lower cost share / risk, higher premium plans. As with our other analysis, we find interesting results for non-white employees. Even after controlling for a number of other factors, non-whites are less likely to switch to one of these new lower risk plans. Again, this may be due to tighter family budget constraints that don't allow for the higher premium associated with one of these lower risk plans.

Our findings are subject to several limitations. As mentioned above, a limitation that is common for studies using employee-level data provided by a firm is that we have no information on spousal insurance options if the spouse is not an employee of the university. This implies that we may not be observing the complete health benefit choice set for married employees. To address this issue, we also estimated our models on 
samples restricted to single employees. The fact that the results do not change dramatically when the data is restricted to singles suggests that this is not a major concern. A second issue is that we do not have data on the health status and health care consumption of employees. These are controlled for only to the extent that health status and health care consumption are correlated with employee demographic characteristics. Of course, as is evident from the state of the literature, there is perhaps no data source that provides detailed data on FSA and health plan consumption for families along with detailed data on health. However, such data may be very important in assessing whether existing health plans and FSAs efficiently meet the needs of workers and households. 


\section{REFERENCES}

Bhattacharya J, Schoenbaum M, Sood N. 2002. Optimal Contributions to Flexible Spending Accounts. Economics Letters 76(1): 129-135.

Cardon J, Showalter M. 2001. An Examination of Flexible Spending Accounts. Journal of Health Economics 20(6): 935-954.

Cardon J, Showalter M. 2003. Flexible Spending Accounts as Insurance. Journal of Risk and Insurance 70(1): 43-51.

Cardon J, Showalter M. 2007. Insurance Choice and Tax-Preferred Health Savings Accounts. Journal of Health Economics 26(2): 373-399.

Cutler DM, Reber SJ. 1998. Paying for Health Insurance: The Trade-Off Between Competition and Adverse Selection. Quarterly Journal of Economics 113(2): 433-466.

Dowd B, Feldman R. 1994 / 1995. Premium Elasticities of Health Plan Choice. Inquiry 31(4): 438-444.

Dranove D, Spier K, Baker L. 2000. Competition Among Employers Offering Health Insurance. Journal of Health Economics 19(1): 121-140.

Duan N, Manning WG, Morris CN et al. 1984. Choosing Between the Sample Selection Model and the Multi-Part Model. Journal of Business and Economic Statistics 2(3): 283289.

Feenburg D, Coutts E. 1993. An Introduction to the TAXSIM Model. Journal of Policy Analysis and Management 12(1): 189-194.

Feldman R, Finch, M, Dowd B et al. 1989. The Demand for Employment-Based Health Insurance Plans. Journal of Human Resources 24(1): 115-142.

Gruber J, McKnight R. 2003. Why did Employee Health Insurance Contributions Rise? Journal of Health Economics 22(6): 1085-1104.

Harris K, Schultz J, Feldman R. 2002. Measuring Consumer Perceptions of Quality Differences among Competing Health Benefit Plans. Journal of Health Economics 21(1): $1-17$.

Jack W, Levinson A, Rahardja S. 2006. Employee cost-sharing and the welfare effects of Flexible Spending Accounts. Journal of Public Economics 90(12): 2285-2301.

Joint Committee on Taxation. 2005. Estimates of Federal Tax Expenditures for Fiscal Years 2005-2009, JCS-1-05, US Government Printing Office, Washington DC.

Kaiser Family Foundation and Health Research and Educational Trust. 2003. Employer Health Benefits 2003 Annual Survey, Kaiser Family Foundation, Washington DC. 
Levy H. 1998. Who Pays for Health Insurance? Employee Contributions to Health Insurance Premiums. Princeton University Industrial Relations Section Working Paper 398, Princeton University.

Madrian BC, Shea DF. 2001. The Power of Suggestion: Inertia in 401(k) Participation and Savings Behavior. Quarterly Journal of Economics 116(4): 1149-1525.

Parente ST, Feldman R, Christianson JB. 2004. Employee Choice of Consumer-Driven Health Insurance in a Multiplan, Multiproduct Setting. Health Services Research 29(4) Part II: 1091-1111. 
Table 1: Total Monthly Insurance Premiums

(Employee Share in Parenthesis)

\begin{tabular}{|l|c|c|c|}
\hline Insurance Plan: & $\begin{array}{c}\text { Monthly Premium } \\
\mathbf{2 0 0 1}\end{array}$ & $\begin{array}{c}\text { Monthly Premium } \\
\mathbf{2 0 0 2}\end{array}$ & $\begin{array}{c}\text { Monthly Premium } \\
\mathbf{2 0 0 3}\end{array}$ \\
\hline HMO & $\$ 206(\$ 0)$ & $\$ 270(\$ 21)$ & $\$ 296(\$ 21)$ \\
\hline PPO & $\$ 261(\$ 55)$ & $\$ 293(\$ 44)$ & $\$ 324(\$ 49)$ \\
\hline PPO High & N/A & $\$ 324(\$ 75)$ & $\$ 355(\$ 80)$ \\
\hline EPO & N/A & $\$ 328(\$ 79)$ & $\$ 360(\$ 85)$ \\
\hline Consumer-driven & N/A & N/A & $\$ 307(\$ 32)$ \\
\hline
\end{tabular}

Table 2: Descriptive Statistics for Full Sample by Year

\begin{tabular}{|l|c|c|c|}
\hline Variable & $\mathbf{2 0 0 1}$ & $\mathbf{2 0 0 2}$ & $\mathbf{2 0 0 3}$ \\
\hline Avg. Age on June 30 & 44.47 years & 44.47 years & 44.68 years \\
\hline$\%$ Female $* *$ & $55.03 \%$ & $57.20 \%$ & $57.68 \%$ \\
\hline$\%$ Non-white & $15.97 \%$ & $15.44 \%$ & $15.45 \%$ \\
\hline$\%$ Married & $52.72 \%$ & $52.13 \%$ & $51.62 \%$ \\
\hline Avg. Job Tenure on June 30 & 11.09 years & 11.21 years & 11.29 years \\
\hline$\%$ Non-FSA participant ** & $88.66 \%$ & $88.20 \%$ & $87.35 \%$ \\
\hline$\%$ low FSA (\$1,000 or below) & $6.43 \%$ & $6.44 \%$ & $6.82 \%$ \\
\hline$\%$ high FSA (over $\$ 1,000) * *$ & $4.91 \%$ & $5.36 \%$ & $5.83 \%$ \\
\hline $\begin{array}{l}\text { Average Nominal FSA Contribution } \\
\text { for all Employees } * *\end{array}$ & $\$ 141.56$ & $\$ 145.71$ & $\$ 159.00$ \\
\hline $\begin{array}{l}\text { Average Nominal FSA Contribution } \\
\text { among Participants }\end{array}$ & $\$ 1,248.26$ & $\$ 1,235.28$ & $\$ 1,256.86$ \\
\hline$\%$ Faculty ** & & & $18.01 \%$ \\
\hline Average Nominal Yearly Salary $* * *$ & $\$ 44,336.51$ & $\$ 43,781.41$ & $\$ 45,598.39$ \\
\hline$\%$ HMO Enrollee $* *$ & $69.62 \%$ & $68.20 \%$ & $67.89 \%$ \\
\hline$\%$ PPO Enrollee $* * *$ & $17.57 \%$ & $13.59 \%$ & $12.61 \%$ \\
\hline$\%$ PPO High Enrollee $* * *$ & $0 \%$ & $3.61 \%$ & $5.08 \%$ \\
\hline$\%$ EPO Enrollee $* * *$ & $0 \%$ & $1.11 \%$ & $1.47 \%$ \\
\hline$\%$ No Insurance & $12.82 \%$ & $13.42 \%$ & $12.64 \%$ \\
\hline Average \# of Health Dependents $* * *$ & .57 dependents & .57 dependents & .63 dependents \\
\hline Average Marginal Tax Rate *** & .39 & .39 & .37 \\
\hline Sample size & 9,832 & 10,597 & 10,822 \\
\hline
\end{tabular}

* Difference between years significant at $10 \%$

** Difference between years significant at 5\%

*** Difference between years significant at 1\% 
Table 3: Two Part Models of FSA Participation and Contribution Levels

\begin{tabular}{|c|c|c|c|c|c|c|c|c|c|c|}
\hline & \multicolumn{2}{|c|}{ (1) 2001 full sample } & \multicolumn{2}{|c|}{ (2) 2002 full sample } & \multicolumn{2}{|c|}{ (3) 2003 full sample } & \multicolumn{2}{|c|}{ (4) Pooled full sample } & \multicolumn{2}{|c|}{ (5) Pooled Singles } \\
\hline Variable & $\begin{array}{l}F S A \\
\text { participant }\end{array}$ & $\begin{array}{l}\text { Log } \\
\text { election }\end{array}$ & $\begin{array}{l}F S A \\
\text { participant }\end{array}$ & $\begin{array}{l}\text { Log } \\
\text { election }\end{array}$ & $\begin{array}{l}\text { FSA } \\
\text { participant }\end{array}$ & $\begin{array}{l}\text { Log } \\
\text { election }\end{array}$ & $\begin{array}{l}F S A \\
\text { participant }\end{array}$ & $\begin{array}{l}\text { log } \\
\text { election }\end{array}$ & $\begin{array}{l}\text { FSA } \\
\text { participant }\end{array}$ & $\begin{array}{l}\text { Log } \\
\text { election }\end{array}$ \\
\hline Log age & $\begin{array}{l}.43 * * * \\
(.10)\end{array}$ & $\begin{array}{l}.68 * * * \\
(.13) \\
\end{array}$ & $\begin{array}{l}.40 * * * \\
(.10)\end{array}$ & $\begin{array}{l}.47 * * * \\
(.12) \\
\end{array}$ & $\begin{array}{l}.44 * * * \\
(.09)\end{array}$ & $\begin{array}{l}.56 * * * \\
(.11) \\
\end{array}$ & $\begin{array}{l}.88 * * * \\
(.16) \\
\end{array}$ & $\begin{array}{l}.56^{* * *} \\
(.09) \\
\end{array}$ & $\begin{array}{l}1.09 * * * \\
(.20)\end{array}$ & $\begin{array}{l}.59 * * * \\
(.13) \\
\end{array}$ \\
\hline Female & $\begin{array}{l}.17 * * * \\
(.04) \\
\end{array}$ & $\begin{array}{l}-.01 \\
(.05) \\
\end{array}$ & $\begin{array}{l}.12 * * * \\
(.04) \\
\end{array}$ & $\begin{array}{l}-.01 \\
(.04) \\
\end{array}$ & $\begin{array}{l}.18 * * * \\
(.04)\end{array}$ & $\begin{array}{l}-.01 \\
(.04) \\
\end{array}$ & $\begin{array}{l}.35 * * * \\
(.06) \\
\end{array}$ & $\begin{array}{l}.03 \\
(.04) \\
\end{array}$ & $\begin{array}{l}.40^{* * *} \\
(.09) \\
\end{array}$ & $\begin{array}{l}-.07 \\
(.06) \\
\end{array}$ \\
\hline Married & $\begin{array}{l}.28 * * * \\
(.04)\end{array}$ & $\begin{array}{l}.20 * * * \\
(.05)\end{array}$ & $\begin{array}{l}.20^{* * *} \\
(.04)\end{array}$ & $\begin{array}{l}.18^{* * *} \\
(.05)\end{array}$ & $\begin{array}{l}.23 * * * \\
(.04)\end{array}$ & $\begin{array}{l}.20 * * * \\
(.05)\end{array}$ & $\begin{array}{l}.43 * * * \\
(.07)\end{array}$ & $\begin{array}{l}.20 * * * \\
(.04)\end{array}$ & $\mathrm{N} / \mathrm{A}$ & N/A \\
\hline Nonwhite & $\begin{array}{l}-.28 * * * \\
(.06) \\
\end{array}$ & $\begin{array}{l}-.23 * * \\
(.09) \\
\end{array}$ & $\begin{array}{l}-.23 * * * \\
(.05) \\
\end{array}$ & $\begin{array}{l}-.22 * * * \\
(.07) \\
\end{array}$ & $\begin{array}{l}-.21^{* * *} \\
(.05) \\
\end{array}$ & $\begin{array}{l}-.18^{* *} \\
(.07)\end{array}$ & $\begin{array}{l}-.45 * * * \\
(.09)\end{array}$ & $\begin{array}{l}-.22 * * * \\
(.06)\end{array}$ & $\begin{array}{l}-.61^{* * * *} \\
(.12)\end{array}$ & $\begin{array}{l}.06 \\
(.10)\end{array}$ \\
\hline Log tenure & $\begin{array}{l}.16^{* * * *} \\
(.02) \\
\end{array}$ & $\begin{array}{l}.02 \\
(.03) \\
\end{array}$ & $\begin{array}{l}.17^{* * * *} \\
(.02) \\
\end{array}$ & $\begin{array}{l}.05 * \\
(.03) \\
\end{array}$ & $\begin{array}{l}.18 * * * \\
(.02) \\
\end{array}$ & $\begin{array}{l}.10 * * * \\
(.03)\end{array}$ & $\begin{array}{l}.44 * * * \\
(.04)\end{array}$ & $\begin{array}{l}.06 * * * \\
(.02) \\
\end{array}$ & $\begin{array}{l}.30 * * * \\
(.05) \\
\end{array}$ & $\begin{array}{l}.08 * * \\
(.03)\end{array}$ \\
\hline Faculty & $\begin{array}{l}.12 * * \\
(.05) \\
\end{array}$ & $\begin{array}{l}.02 \\
(.05) \\
\end{array}$ & $\begin{array}{l}.12 * * \\
(.05) \\
\end{array}$ & $\begin{array}{l}.02 \\
(.05) \\
\end{array}$ & $\begin{array}{l}.05 \\
(.05) \\
\end{array}$ & $\begin{array}{l}.07 \\
(.05) \\
\end{array}$ & $\begin{array}{l}.24 * * * \\
(.08) \\
\end{array}$ & $\begin{array}{l}.01 \\
(.04) \\
\end{array}$ & $\begin{array}{l}.04 \\
(.12) \\
\end{array}$ & $\begin{array}{l}.08 \\
(.07) \\
\end{array}$ \\
\hline Log salary & $\begin{array}{l}.54 * * * \\
(.05) \\
\end{array}$ & $\begin{array}{l}.27 * * * \\
(.05) \\
\end{array}$ & $\begin{array}{l}.54 * * * \\
(.04) \\
\end{array}$ & $\begin{array}{l}.23 * * * \\
(.05) \\
\end{array}$ & $\begin{array}{l}.56 * * * \\
(.04)\end{array}$ & $\begin{array}{l}.20 * * * \\
(.05) \\
\end{array}$ & $\begin{array}{l}1.20 * * * \\
(.07)\end{array}$ & $\begin{array}{l}.24 * * * \\
(.04) \\
\end{array}$ & $\begin{array}{l}1.06^{* * *} \\
(.11)\end{array}$ & $\begin{array}{l}.19^{* * *} \\
(.06)\end{array}$ \\
\hline MTR & $\begin{array}{l}1.78 * * * \\
(.36)\end{array}$ & $\begin{array}{l}-.17 \\
(.39) \\
\end{array}$ & $\begin{array}{l}1.21 * * * \\
(.36)\end{array}$ & $\begin{array}{l}.08 \\
(.36) \\
\end{array}$ & $\begin{array}{l}1.54 * * * \\
(.42)\end{array}$ & $\begin{array}{l}-.21 \\
(.45) \\
\end{array}$ & $\begin{array}{l}2.32 * * * \\
(.54)\end{array}$ & $\begin{array}{l}.02 \\
(.24)\end{array}$ & $\begin{array}{l}1.99^{* * *} \\
(.74)^{4}\end{array}$ & $\begin{array}{l}-.42 \\
(.44)\end{array}$ \\
\hline 2002 dummy & N/A & N/A & N/A & N/A & N/A & N/A & $\begin{array}{l}.10 * * \\
(.04) \\
\end{array}$ & $\begin{array}{l}.02 \\
(.02)\end{array}$ & $\begin{array}{l}.14^{* *} \\
(.06) \\
\end{array}$ & $\begin{array}{l}.03 \\
(.03) \\
\end{array}$ \\
\hline 2003 dummy & N/A & N/A & N/A & N/A & N/A & N/A & $\begin{array}{l}.24 * * * \\
(.04)\end{array}$ & $\begin{array}{l}.05^{* * * *} \\
(.02)\end{array}$ & $\begin{array}{l}.27 * * * \\
(.06)\end{array}$ & $\begin{array}{l}.04 \\
(.03) \\
\end{array}$ \\
\hline $\mathrm{N}$ & 9,832 & 1,115 & 10,597 & 1,250 & 10,822 & 1,369 & 12,930 & 1,776 & 6,303 & 667 \\
\hline Pseudo R2 & .13 & .13 & .12 & .11 & .11 & .14 & & .13 & & .09 \\
\hline Log Likelihood & $-3,021$ & & $-3,394$ & & $-3,649$ & & $-7,177$ & & $-2,963$ & \\
\hline
\end{tabular}

- Heteroskedastic-robust standard errors are in parentheses.

- * Coefficient statistically significant at $10 \% \quad * * \quad$ at $5 \% \quad * * * \quad$ at $1 \%$

Table 4: Two Part Models with Controls for Insurance Choice

\begin{tabular}{|c|c|c|c|c|c|c|c|c|c|c|}
\hline & \multicolumn{2}{|c|}{ (1) 2001 full sample } & \multicolumn{2}{|c|}{ (2) 2002 full sample } & \multicolumn{2}{|c|}{ (3) 2003 full sample } & \multicolumn{2}{|c|}{ (4) Pooled full sample } & \multicolumn{2}{|c|}{ (5) Pooled Singles } \\
\hline Variable & $\begin{array}{l}F S A \\
\text { participant }\end{array}$ & $\begin{array}{l}\text { log } \\
\text { election }\end{array}$ & $\begin{array}{l}F S A \\
\text { participant }\end{array}$ & $\begin{array}{l}\text { Log } \\
\text { election }\end{array}$ & $\begin{array}{l}\text { FSA } \\
\text { participant }\end{array}$ & $\begin{array}{l}\text { Log } \\
\text { election }\end{array}$ & $\begin{array}{l}F S A \\
\text { participant }\end{array}$ & $\begin{array}{l}\text { log } \\
\text { election }\end{array}$ & $\begin{array}{l}\text { FSA } \\
\text { participant }\end{array}$ & $\begin{array}{l}\text { Log } \\
\text { election }\end{array}$ \\
\hline $\mathrm{HMO}$ & $\begin{array}{l}.32 * * * \\
(.07)\end{array}$ & $\begin{array}{l}.07 \\
(.08)\end{array}$ & $\begin{array}{l}.30 * * * \\
(.07)\end{array}$ & $\begin{array}{l}-.06 \\
(.07)\end{array}$ & $\begin{array}{l}.26 * * * \\
(.07)\end{array}$ & $\begin{array}{l}-.16 * * \\
(.07)\end{array}$ & $\begin{array}{l}.63 * * * \\
(.10)\end{array}$ & $\begin{array}{l}-.02 \\
(.05)\end{array}$ & $\begin{array}{l}.52 * * * \\
(.16)\end{array}$ & $\begin{array}{l}-.06 \\
(.10)\end{array}$ \\
\hline PPO & $\begin{array}{l}1.86 * * * \\
(.36)\end{array}$ & $\begin{array}{l}-.13 \\
(.39) \\
\end{array}$ & $\begin{array}{l}.49 * * * \\
(.09)\end{array}$ & $\begin{array}{l}.15 \\
(.09)\end{array}$ & $\begin{array}{l}.36 * * * \\
(.08)\end{array}$ & $\begin{array}{l}.07 \\
(.08)\end{array}$ & $\begin{array}{l}.87 * * * \\
(.13)\end{array}$ & $\begin{array}{l}.03 \\
(.06)\end{array}$ & $\begin{array}{l}.49 * * \\
(.22) \\
\end{array}$ & $\begin{array}{l}.04 \\
(.12)\end{array}$ \\
\hline PPO High & N/A & N/A & $\begin{array}{l}.64^{* * *} \\
(.14)\end{array}$ & $\begin{array}{l}.03 \\
(.13)\end{array}$ & $\begin{array}{l}.42 * * * \\
(.13)\end{array}$ & $\begin{array}{l}.10 \\
(.12)\end{array}$ & $\begin{array}{l}1.07 * * * \\
(.21)\end{array}$ & $\begin{array}{l}.09 \\
(.07)\end{array}$ & $\begin{array}{l}.92 * * * \\
(.29) \\
\end{array}$ & $\begin{array}{l}.14 \\
(.14)\end{array}$ \\
\hline EPO & N/A & $\mathrm{N} / \mathrm{A}$ & $\begin{array}{l}1.29 * * * \\
(.36)\end{array}$ & $\begin{array}{l}.13 \\
(.36)\end{array}$ & $\begin{array}{l}1.59 * * * \\
.42\end{array}$ & $\begin{array}{l}-.19 \\
(.45)\end{array}$ & $\begin{array}{l}2.42 * * * \\
(.55)\end{array}$ & $\begin{array}{l}.03 \\
(.24)\end{array}$ & $\begin{array}{l}2.05 * * * \\
(.74)\end{array}$ & $\begin{array}{l}-.43 \\
(.44) \\
\end{array}$ \\
\hline 2002 dummy & N/A & N/A & $\mathrm{N} / \mathrm{A}$ & N/A & $\mathrm{N} / \mathrm{A}$ & N/A & $\begin{array}{l}.08^{*} \\
(.04)\end{array}$ & $\begin{array}{l}.01 \\
(.02)\end{array}$ & $\begin{array}{l}.14^{* *} \\
(.06)\end{array}$ & $\begin{array}{l}.02 \\
(.03)\end{array}$ \\
\hline 2003 dummy & N/A & N/A & N/A & N/A & N/A & N/A & $\begin{array}{l}.21 * * * \\
(.04)\end{array}$ & $\begin{array}{l}.04 * * \\
.02)\end{array}$ & $\begin{array}{l}.26 * * * \\
(.06)\end{array}$ & $\begin{array}{l}.03 \\
(.03)\end{array}$ \\
\hline $\mathrm{N}$ & 9,832 & 1,115 & 10,597 & 1,250 & 10,822 & 1,369 & 12,930 & 1,776 & 6,303 & 667 \\
\hline Pseudo R2 & .13 & .13 & .12 & .12 & .12 & .15 & & .13 & & .09 \\
\hline Log Likelihood & $-3,008$ & & $-3,368$ & & $-3,630$ & & $-7,143$ & & $-2,955$ & \\
\hline
\end{tabular}

- $\quad$ Each specification also includes the independent variables from Table 3.

- Heteroskedastic-robust standard errors are in parentheses.

- * Coefficient statistically significant at $10 \% \quad * * \quad$ at $5 \% \quad * * *$ at $1 \%$ 
Table 5: Conditional Logit Model of Health Plan Bundle, by Year (Excluded Category is No Coverage, No FSA Contribution)

\begin{tabular}{|c|c|c|c|c|}
\hline Variable & $\begin{array}{c}\text { (1) } \\
2001 \text { Full Sample } \\
\text { Beta (s.e.) } \\
\end{array}$ & $\begin{array}{c}\text { (2) } \\
2003 \text { Full Sample } \\
\text { Beta (s.e.) } \\
\end{array}$ & $\begin{array}{c}\text { (3) } \\
2001 \text { Singles } \\
\text { Beta (s.e.) } \\
\end{array}$ & $\begin{array}{c}(4) \\
2003 \text { Singles } \\
\text { Beta (s.e.) } \\
\end{array}$ \\
\hline \multicolumn{5}{|c|}{ Health Benefit Bundle Intercepts $\left(\alpha_{b}\right)$ : } \\
\hline$(\mathrm{HMO}, \mathrm{NO} F S A)$ indicator & $1.95(.08) * * *$ & $1.86(.08) * * *$ & $1.91(.10) * * *$ & $1.84(.10) * * *$ \\
\hline$(\mathrm{PPO}, \mathrm{NO} F S A)$ indicator & $-.49(.14) * * *$ & $-.30(.10) * * *$ & $-.81(.10) * *$ & $-.40(.14) * * *$ \\
\hline (PPO High, NO FSA) indicator & & $-2.07(.14) * * *$ & & $-2.04(.21) * * *$ \\
\hline (NO Cov, FSA) indicator & $-4.86(.40) * * *$ & $-4.11(.41) * * *$ & $-5.42(.66) * * *$ & $-4.10(.60) * * *$ \\
\hline (HMO, FSA) indicator & $-2.34(.30) * * *$ & $-2.03(.33) * * *$ & $-3.09(.46) * * *$ & $-1.76(.44) * * *$ \\
\hline (PPO, FSA) indicator & $-4.39(.34) * * *$ & $-3.86(.36) * * *$ & $-5.23(.58) * * *$ & $-3.70(.49) * * *$ \\
\hline (PPO High, FSA) indicator & & $-5.39(.40) * * *$ & & $-4.97(.57) * * *$ \\
\hline \multicolumn{5}{|c|}{$\begin{array}{l}\text { Employee Characteristic Interactions } \\
\text { with Bundle Indicators }\left(\gamma_{\mathrm{b}}\right) \text { : }\end{array}$} \\
\hline \multicolumn{5}{|l|}{ Log age coefficients: } \\
\hline (HMO, NO FSA) & $-.94(.17) * * *$ & $-.78(.16) * * *$ & $-.43(.27)$ & $-.72(.24) * * *$ \\
\hline$(\mathrm{PPO}, \mathrm{NO} F S A)$ & $.63(.21) * * *$ & $.39(.21) *$ & $1.03(.32) * * *$ & $.12(.31)$ \\
\hline (PPO High, NO FSA) & & $1.66(.28) * * *$ & & $1.29(.41) * * *$ \\
\hline (NO Cov, FSA) & $-.25(.61)$ & $.72(.56)$ & $.22(1.50)$ & $1.79(1.09)$ \\
\hline (HMO, FSA) & $.21(.29)$ & $.02(.36)$ & $1.28(.46) * * *$ & $.41(.39)$ \\
\hline$(\mathrm{PPO}, \mathrm{FSA})$ & $.67(.42)$ & $1.28(.43) * * *$ & $1.22(.69) *$ & $1.45(.68) * *$ \\
\hline$(\mathrm{PPO}$ High, FSA $)$ & & $1.90(.54) * * *$ & & $.92(.90)$ \\
\hline \multicolumn{4}{|l|}{ Married coefficients: } & N/A \\
\hline$(\mathrm{PPO}, \mathrm{NO} F \mathrm{FA})$ & $-1.23(.09) * * *$ & $-1.46(.09) * * *$ & N/A & N/A \\
\hline (PPO High, NO FSA) & & $-1.48(.11) * * *$ & & \\
\hline (NO Cov, FSA) & $.83(.26) * * *$ & $.39(.22) *$ & N/A & N/A \\
\hline (HMO, FSA) & $-.60(.11) * * *$ & $-.79(.11) * * *$ & N/A & N/A \\
\hline$(\mathrm{PPO}, \mathrm{FSA})$ & $-.76(.15) * * *$ & $-1.01(.16) * * *$ & $\mathrm{~N} / \mathrm{A}$ & N/A \\
\hline (PPO High, FSA) & & $-.75(.20) * * *$ & & \\
\hline \multicolumn{5}{|l|}{ Nonwhite coefficients: } \\
\hline$(\mathrm{PPO}, \mathrm{NO} F \mathrm{FA})$ & $-.27(.13) * *$ & $-.15(.13)$ & $-.22(.18)$ & $-.19(.18)$ \\
\hline (PPO High, NO FSA) & & $-.33(.18) *$ & & $-.39(.25)$ \\
\hline (NO Cov, FSA) & $-.84(.47) *$ & $-.46(.38)$ & $-13.91(726.30)$ & $-.25(.63)$ \\
\hline (HMO, FSA) & $-.11(.16)$ & $.11(.15)$ & $-.36(.28)$ & $-.52(.25) * *$ \\
\hline (PPO, FSA) & $-.59(.27) * *$ & $-.54(.29)^{*}$ & $-.60(.45)$ & $-.51(42)$ \\
\hline (PPO High, FSA) & & $-.94(.40) * *$ & & $-.59(.62)$ \\
\hline \multicolumn{5}{|l|}{ Log Salary coefficients: } \\
\hline (HMO, NO FSA) & $.04(.07)$ & $.16(.07)^{* *}$ & $.39(.12) * * *$ & $.44(.11) * * *$ \\
\hline$(\mathrm{PPO}, \mathrm{NO} F S A)$ & $.15(.09) *$ & $.18(.09) *$ & $.48(.14) * * *$ & $.46(.15) * * *$ \\
\hline (PPO High, NO FSA) & & $.74(.12) * * *$ & & $1.21(.19) * * *$ \\
\hline (NO Cov, FSA) & $.96(.25) * * *$ & $1.08(.22) * * *$ & $1.72(.58) * * *$ & $1.53(.45) * * *$ \\
\hline (HMO, FSA) & $.91(.12) * * *$ & $1.12(.11) * * *$ & $1.30(.20) * * *$ & $1.43(.18) * * *$ \\
\hline$(\mathrm{PPO}, \mathrm{FSA})$ & $1.24(.15) * * *$ & $1.18(.16) * * *$ & $1.66(.26) * * *$ & $1.39(.27) * * *$ \\
\hline (PPO High, FSA) & & $1.28(.18) * * *$ & & $2.19(.35) * * *$ \\
\hline \multicolumn{5}{|l|}{ Plan \& Person Specific Variables: } \\
\hline
\end{tabular}




\begin{tabular}{|c|c|c|c|c|}
\hline $\begin{array}{l}\text { Tax adjusted premium } \\
\text { FSA tax savings }\end{array}$ & $\begin{array}{l}.03(.003) * * * \\
.004(.001)^{* * *}\end{array}$ & $\begin{array}{r}.02(.001) * * * \\
.003(.001) * * *\end{array}$ & $\begin{array}{r}.03(.01) * * * \\
.005(.001) * * *\end{array}$ & $\begin{array}{l}.02(.02) * * * \\
.002(.001) * *\end{array}$ \\
\hline $\mathrm{N}$ & 9,832 & 10,822 & 4,649 & 5,236 \\
\hline Pseudo R2 & .41 & .41 & .47 & .46 \\
\hline Log likelihood & $-10,323$ & $-13,232$ & $-4,398$ & $-5,872$ \\
\hline Prob of (NO Cov, NO FSA) & $11.71 \%$ & $11.40 \%$ & $8.17 \%$ & $7.91 \%$ \\
\hline Prob of (HMO, NO FSA) & $62.40 \%$ & $60.24 \%$ & $68.79 \%$ & $66.35 \%$ \\
\hline Prob of (PPO, NO FSA) & $14.55 \%$ & $10.68 \%$ & $14.99 \%$ & $11.19 \%$ \\
\hline Prob of (PPO High, NO FSA) & & $5.03 \%$ & & $4.77 \%$ \\
\hline Prob of (NO Cov, FSA) & $1.11 \%$ & $1.24 \%$ & $.45 \%$ & $.65 \%$ \\
\hline Prob of (HMO, FSA) & $7.22 \%$ & $7.65 \%$ & $5.31 \%$ & $6.26 \%$ \\
\hline Prob of (PPO, FSA) & $3.01 \%$ & $2.24 \%$ & $2.28 \%$ & $1.76 \%$ \\
\hline Prob of (PPO High, FSA) & & $1.52 \%$ & & $.88 \%$ \\
\hline
\end{tabular}

- Log age, Log tenure, and Log salary constructed as deviations from sample mean values.

- Female, Log tenure, and faculty indicators are included in the model, but the results are omitted.

- * Coefficient statistically significant at $10 \% \quad * * \quad$ at $5 \% \quad * * * \quad$ at $1 \%$ 
Table 6: Multinomial Logit Model of Bundle Switching Between 2001 and 2003

(Dependent variable is switching to new plan status:

no switch (S), switch to PPO High or EPO with no FSA (B4), or switch to PPO High or EPO

with FSA (B8))

(excluded category: no switch (S))

\begin{tabular}{|c|c|c|c|c|}
\hline Variables & $\begin{array}{l}(1) \\
\text { Switch to PPO } \\
\text { High or EPO } \\
\text { with no FSA (B4) } \\
2001-2003 \\
\text { (Full Sample) } \\
\text { Beta (s.e.) }\end{array}$ & $\begin{array}{l}(2) \\
\text { Switch to PPO } \\
\text { High or EPO } \\
\text { with FSA (B8) } \\
\text { 2001-2003 } \\
\text { (Full Sample) } \\
\text { Beta (s.e.) }\end{array}$ & $\begin{array}{l}\text { (3) } \\
\text { Switch to PPO } \\
\text { High or EPO } \\
\text { with no FSA (B4) } \\
\text { 2001-2003 } \\
\text { (Singles) } \\
\text { Beta (s.e.) }\end{array}$ & $\begin{array}{l}\text { (4) } \\
\text { Switch to PPO } \\
\text { High or EPO } \\
\text { with FSA (B8) } \\
\text { 2001-2003 } \\
\text { (Singles) } \\
\text { Beta (s.e.) }\end{array}$ \\
\hline \multicolumn{5}{|l|}{ Demographics: } \\
\hline Constant & $-13.37(1.70) * * *$ & $-16.70(2.96) * * *$ & $-15.18(2.74) * * *$ & $-23.47(5.42) * * *$ \\
\hline Log age & $1.04(.33) * * *$ & $.88(.59)$ & $.72(.47)$ & $.31(1.02)$ \\
\hline Female & $.47(.12) * * *$ & $.34(.20) *$ & $.44(.18) * *$ & $.47(.39)$ \\
\hline Married & $.10(.14)$ & $.61(.23) * *$ & $\mathrm{~N} / \mathrm{A}$ & $\mathrm{N} / \mathrm{A}$ \\
\hline Nonwhite & $-.38(.19) * *$ & $-.61(.41)$ & $-.27(.25)$ & $-.45(.76)$ \\
\hline Log tenure & $.08(.09)$ & $-.35(.16) * *$ & $.22(.14)$ & $-.58(.30) *$ \\
\hline Faculty & $-.09(.17)$ & $.14(.24)$ & $-.47(.29)$ & $-.90(.50) *$ \\
\hline Log salary & $.48(.14) * * *$ & $.71(.21) * * *$ & $.72(.23) * * *$ & $1.56(.40) * * *$ \\
\hline MTR & $-.72(1.41)$ & $.85(2.15)$ & $-.40(1.81)$ & $2.31(3.37)$ \\
\hline \multicolumn{5}{|l|}{ Insurance Bundle Choice in 2001: } \\
\hline (PPO, No FSA) 2001 & $2.85(.13) * * *$ & $2.26(.32) * * *$ & $2.87(.18) * * *$ & $2.11(.48) * * *$ \\
\hline (No insurance, No FSA) 2001 & $.68(.20) * * *$ & $-.65(.75)$ & $.86(.32) * * *$ & -- \\
\hline$(\mathrm{HMO}, \mathrm{FSA}) 2001$ & $-1.91(.72) * * *$ & $1.78(.37) * * *$ & -- & $1.64(.68) * *$ \\
\hline (PPO, FSA) 2001 & $.42(.44)$ & $4.72(.30) * * *$ & $.98(.56) *$ & $4.53(.48) * * *$ \\
\hline (No insurance, FSA) 2001 & $-.81(1.02)$ & $2.22(.58) * * *$ & -- & -- \\
\hline $\begin{array}{l}\mathrm{N} \\
\text { Pseudo R2 } \\
\text { Log Likelihood }\end{array}$ & $\begin{array}{r}8,901 \\
.27 \\
-1814.60 \\
\end{array}$ & & $\begin{array}{r}4,227 \\
.24 \\
-768.08 \\
\end{array}$ & \\
\hline $\begin{array}{l}\text { Prob of No Bundle Change } \\
2001-2003 \\
\text { Prob of switch to PPO High or } \\
\text { EPO with no FSA } \\
2001-2003 \\
\text { Prob of switch to PPO High or } \\
\text { EPO with an FSA } \\
2001-2003\end{array}$ & $93 \%$ & & $5 \%$ & \\
\hline
\end{tabular}

- The base category is no switch to a new plan.

- The excluded insurance bundle choice in 2001 is (HMO, No FSA).

- * Coefficient statistically significant at $10 \% \quad * * \quad$ at $5 \% \quad * * * \quad$ at $1 \%$

- Note that the coefficients on (No insurance, FSA) 2001 are restricted to be zero for 2003 choices B4 and B8 in the singles sample. In addition the coefficient on (HMO, FSA) 2001 is restricted to be zero for 2003 choice B4 in the singles sample and the coefficient on (No insurance, No FSA) 2001 is restricted to be zero for 2003 choice B8 in the singles sample. This is because single individuals with these bundles in 2001 were highly unlikely to switch to one of the new plans by 2003 . 
Figure 1: Histogram for Positive FSA Contributions 2001-2003

Figure 1

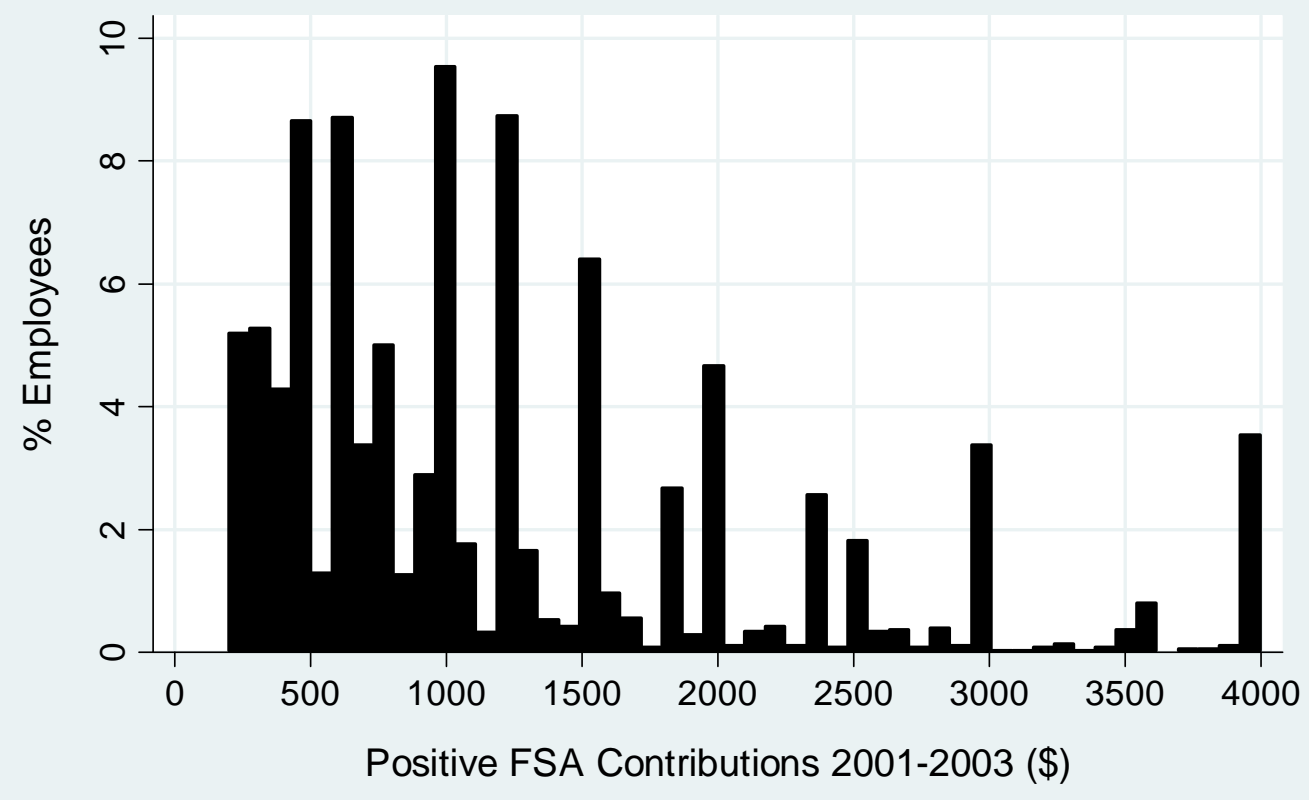

Note:

Over the three year period, the participation rate in the FSA program is $12 \%$. Therefore $88 \%$ of the sample is excluded from the histogram in order to avoid a large spike at $\$ 0$. 


\section{Appendix}

This appendix replicates some of the analysis from the paper using the unmarried sub-population ("singles") in the data. The results presented in the paper represent the full sample. Because the married employees may have been offered health benefits from their spouse's employer, it may be of interest to examine the single employees only. It may be more likely that we are observing the entire choice set for the single employees.

Table A2: Descriptive Statistics for 2001 (Married vs. Single)

\begin{tabular}{|c|c|c|c|}
\hline Variable & $\begin{array}{c}\text { Full Sample } \\
2001 \\
\end{array}$ & Married 2001 & Single 2001 \\
\hline Avg. Age on June $30 * * *$ & 44.47 years & 45.39 years & 43.46 years \\
\hline$\%$ Female $* * *$ & $55.03 \%$ & $48.89 \%$ & $61.88 \%$ \\
\hline$\%$ Non-white $* * *$ & $15.97 \%$ & $13.89 \%$ & $18.28 \%$ \\
\hline$\%$ Married $* * *$ & $52.72 \%$ & $100 \%$ & $0 \%$ \\
\hline Avg. Job Tenure on June $30 * * *$ & 11.09 years & 11.61 years & 10.50 years \\
\hline$\%$ Non-FSA participant $* * *$ & $88.66 \%$ & $85.70 \%$ & $91.96 \%$ \\
\hline$\%$ low FSA $(\$ 1,000$ or below $) * * *$ & $6.43 \%$ & $7.39 \%$ & $5.36 \%$ \\
\hline$\%$ high FSA (over $\$ 1,000) * * *$ & $4.91 \%$ & $6.91 \%$ & $2.69 \%$ \\
\hline $\begin{array}{l}\text { Average Nominal FSA Contribution } \\
\text { for all Employees } * * *\end{array}$ & $\$ 141.56$ & $\$ 195.46$ & $\$ 81.47$ \\
\hline $\begin{array}{l}\text { Average Nominal FSA Contribution } \\
\text { among Participants } * * *\end{array}$ & $\$ 1,248.26$ & $\$ 1,367.13$ & $\$ 1,012.76$ \\
\hline$\%$ Faculty $* * *$ & $19.64 \%$ & $24.72 \%$ & $13.98 \%$ \\
\hline Average Nominal Yearly Salary $* * *$ & $\$ 44,336.51$ & $\$ 50,331.35$ & $\$ 37,653.08$ \\
\hline$\%$ HMO Enrollee $* * *$ & $69.62 \%$ & $65.60 \%$ & $74.10 \%$ \\
\hline$\%$ PPO Enrollee & $17.57 \%$ & $17.83 \%$ & $17.27 \%$ \\
\hline$\%$ No Insurance $* * *$ & $12.82 \%$ & $16.57 \%$ & $8.63 \%$ \\
\hline Average \# of Health Dependents *** & .57 dependents & .85 dependents & .25 dependents \\
\hline Average Marginal Tax Rate $* * *$ & .39 & .37 & .41 \\
\hline Sample size & 9,832 & 5,183 & 4,649 \\
\hline
\end{tabular}

* Difference between years significant at $10 \%$

** Difference between years significant at 5\%

*** Difference between years significant at $1 \%$ 
Table A3: Two Part Models of FSA Participation and Contribution Levels, Singles Sample

\begin{tabular}{|c|c|c|c|c|c|c|c|c|}
\hline & \multicolumn{2}{|c|}{ (1) 2001 singles } & \multicolumn{2}{|c|}{ (2) 2002 singles } & \multicolumn{2}{|c|}{ (3) 2003 singles } & \multicolumn{2}{|c|}{ (4) Pooled singles } \\
\hline Variable & $\begin{array}{l}\text { FSA } \\
\text { participant }\end{array}$ & $\begin{array}{l}\text { log } \\
\text { election }\end{array}$ & $\begin{array}{l}\text { FSA } \\
\text { participant }\end{array}$ & $\begin{array}{l}\text { Log } \\
\text { election }\end{array}$ & $\begin{array}{l}F S A \\
\text { participant }\end{array}$ & $\begin{array}{l}\log \\
\text { election }\end{array}$ & $\begin{array}{l}F S A \\
\text { participant }\end{array}$ & $\begin{array}{l}\text { log } \\
\text { election }\end{array}$ \\
\hline Log age & $\begin{array}{l}.68 * * * \\
(.16)\end{array}$ & $\begin{array}{l}.64 * * * \\
(.20)\end{array}$ & $\begin{array}{l}.54 * * * \\
(.14)\end{array}$ & $\begin{array}{l}.56 * * * \\
(.18)\end{array}$ & $\begin{array}{l}.57 * * * \\
(.14)\end{array}$ & $\begin{array}{l}.68^{* * *} \\
(.16)\end{array}$ & $\begin{array}{l}1.09 * * * \\
(.20)\end{array}$ & $\begin{array}{l}.59 * * * \\
(.13)\end{array}$ \\
\hline Female & $\begin{array}{l}.25 * * * \\
(.06)\end{array}$ & $\begin{array}{l}-.08 \\
(.08)\end{array}$ & $\begin{array}{l}.15 * * * \\
(.06)\end{array}$ & $\begin{array}{l}-.04 \\
(.07)\end{array}$ & $\begin{array}{l}.22 * * * \\
(.06)\end{array}$ & $\begin{array}{l}-.04 \\
(.07)\end{array}$ & $\begin{array}{l}.40 * * * \\
(.09)\end{array}$ & $\begin{array}{l}-.07 \\
(.06)\end{array}$ \\
\hline Nonwhite & $\begin{array}{l}-.34 * * * \\
(.10)\end{array}$ & $\begin{array}{l}-.05 \\
(.17)\end{array}$ & $\begin{array}{l}-.39^{* * *} \\
(.09)\end{array}$ & $\begin{array}{l}-.17 \\
(.14) \\
\end{array}$ & $\begin{array}{l}-.33^{* * *} \\
(.08)\end{array}$ & $\begin{array}{l}.06 \\
(.12)\end{array}$ & $\begin{array}{l}-.61^{* * *} \\
(.12)^{2}\end{array}$ & $\begin{array}{l}-.06 \\
(.10)\end{array}$ \\
\hline Log tenure & $\begin{array}{l}.11 * * * \\
(.04)\end{array}$ & $\begin{array}{l}.05 \\
(.05)\end{array}$ & $\begin{array}{l}.13^{* * *} \\
(.03)\end{array}$ & $\begin{array}{l}.02 \\
(.05)\end{array}$ & $\begin{array}{l}.14^{* * *} \\
(.03)\end{array}$ & $\begin{array}{l}.09 * \\
(.05)\end{array}$ & $\begin{array}{l}.30 * * * \\
(.05)\end{array}$ & $\begin{array}{l}.08 * * \\
(.03)\end{array}$ \\
\hline Faculty & $\begin{array}{l}.02 \\
(.09)\end{array}$ & $\begin{array}{l}.11 \\
(.09)\end{array}$ & $\begin{array}{l}-.0001 \\
(.08)\end{array}$ & $\begin{array}{l}.01 \\
(.09)\end{array}$ & $\begin{array}{l}-.02 \\
(.08)\end{array}$ & $\begin{array}{l}.11 \\
(.09)\end{array}$ & $\begin{array}{l}.04 \\
(.12)\end{array}$ & $\begin{array}{l}.08 \\
(.07)\end{array}$ \\
\hline Log salary & $\begin{array}{l}.55 * * * \\
(.08)\end{array}$ & $\begin{array}{l}.27 * * * \\
(.09)\end{array}$ & $\begin{array}{l}.54 * * * \\
(.08) \\
\end{array}$ & $\begin{array}{l}.19 * * \\
(.08)\end{array}$ & $\begin{array}{l}.57 * * * \\
(.07) \\
\end{array}$ & $\begin{array}{l}.18 * * \\
(.09)\end{array}$ & $\begin{array}{l}1.06 * * * \\
(.11)\end{array}$ & $\begin{array}{l}.19^{* * *} \\
(.06)\end{array}$ \\
\hline MTR & $\begin{array}{l}2.09 * * * \\
(.53)\end{array}$ & $\begin{array}{l}-.74 \\
(.66) \\
\end{array}$ & $\begin{array}{l}.97 * \\
(.51)\end{array}$ & $\begin{array}{l}-.35 \\
(.57)\end{array}$ & $\begin{array}{l}.97 * \\
(.56)\end{array}$ & $\begin{array}{l}-.31 \\
(.65)\end{array}$ & $\begin{array}{l}1.99 * * * \\
(.74)\end{array}$ & $\begin{array}{l}-.42 \\
(.44) \\
\end{array}$ \\
\hline 2002 dummy & $\mathrm{N} / \mathrm{A}$ & $\mathrm{N} / \mathrm{A}$ & $\mathrm{N} / \mathrm{A}$ & $\mathrm{N} / \mathrm{A}$ & N/A & N/A & $\begin{array}{l}.14 * * \\
(.06)\end{array}$ & $\begin{array}{l}.03 \\
(.03) \\
\end{array}$ \\
\hline 2003 dummy & N/A & N/A & N/A & N/A & N/A & N/A & $\begin{array}{l}.27 * * * \\
(.06)\end{array}$ & $\begin{array}{l}.04 \\
(.03)\end{array}$ \\
\hline $\mathrm{N}$ & 4,649 & 374 & 5,073 & 449 & 5,236 & 503 & 6,303 & 667 \\
\hline Pseudo R2 & .13 & .11 & .10 & .07 & .10 & .10 & & .09 \\
\hline Log Likelihood & $-1,137$ & & $-1,363$ & & $-1,490$ & & $\begin{array}{l}-2,963 \\
\end{array}$ & \\
\hline
\end{tabular}

- Heteroskedastic-robust standard errors are in parentheses.

- * Coefficient statistically significant at $10 \% \quad * * \quad$ at $5 \% \quad$ *** $\quad$ at $1 \%$

Table A4: Two Part Models with Controls for Insurance Choice, Singles Sample

\begin{tabular}{|c|c|c|c|c|c|c|c|c|}
\hline & \multicolumn{2}{|c|}{ (1) 2001 singles } & \multicolumn{2}{|c|}{ (2) 2002 full singles } & \multicolumn{2}{|c|}{ (3) 2003 singles } & \multicolumn{2}{|c|}{ (4) Pooled singles } \\
\hline Variable & $\begin{array}{l}\text { FSA } \\
\text { participant }\end{array}$ & $\begin{array}{l}\text { log } \\
\text { election }\end{array}$ & $\begin{array}{l}\text { FSA } \\
\text { participant }\end{array}$ & $\begin{array}{l}\text { Log } \\
\text { election }\end{array}$ & $\begin{array}{l}F S A \\
\text { participant }\end{array}$ & $\begin{array}{l}\log \\
\text { election }\end{array}$ & $\begin{array}{l}F S A \\
\text { participant }\end{array}$ & $\begin{array}{l}\text { log } \\
\text { election }\end{array}$ \\
\hline $\mathrm{HMO}$ & $\begin{array}{l}.44 * * * \\
(.13)\end{array}$ & $\begin{array}{l}-.004 \\
(.18)\end{array}$ & $\begin{array}{l}.35 * * * \\
(.12)\end{array}$ & $\begin{array}{l}-.23 * \\
(.13)\end{array}$ & $\begin{array}{l}.22 * \\
(.11)\end{array}$ & $\begin{array}{l}.13 \\
(.14) \\
\end{array}$ & $\begin{array}{l}.52 * * * \\
(.16)\end{array}$ & $\begin{array}{l}-.06 \\
(.10)\end{array}$ \\
\hline PPO & $\begin{array}{l}2.20^{* * * *} \\
(.53)^{2}\end{array}$ & $\begin{array}{l}-.68 \\
(.66) \\
\end{array}$ & $\begin{array}{l}.37 * * \\
(.17)\end{array}$ & $\begin{array}{l}.03 \\
(.16) \\
\end{array}$ & $\begin{array}{l}.13 \\
(.14)\end{array}$ & $\begin{array}{l}.13 \\
(.18) \\
\end{array}$ & $\begin{array}{l}.49^{* *} \\
(.22) \\
\end{array}$ & $\begin{array}{l}.04 \\
(.12)\end{array}$ \\
\hline PPO High & $\mathrm{N} / \mathrm{A}$ & N/A & $\begin{array}{l}.73 * * * \\
(.21) \\
\end{array}$ & $\begin{array}{l}-.14 \\
(.17)\end{array}$ & $\begin{array}{l}.34 * \\
(.20)\end{array}$ & $\begin{array}{l}.12 \\
(.23) \\
\end{array}$ & $\begin{array}{l}.92 * * * \\
(.29)\end{array}$ & $\begin{array}{l}.14 \\
(.14)\end{array}$ \\
\hline EPO & N/A & N/A & $\begin{array}{l}1.04 * * \\
(.51)\end{array}$ & $\begin{array}{l}-.29 \\
(.58) \\
\end{array}$ & $\begin{array}{l}.99 * \\
(.56) \\
\end{array}$ & $\begin{array}{l}-.28 \\
(.65) \\
\end{array}$ & $\begin{array}{l}2.05 * * * \\
(.74)\end{array}$ & $\begin{array}{l}-.43 \\
(.44) \\
\end{array}$ \\
\hline 2002 dummy & N/A & $\mathrm{N} / \mathrm{A}$ & N/A & N/A & N/A & N/A & $\begin{array}{l}.14 * * \\
(.06)\end{array}$ & $\begin{array}{l}.02 \\
(.03)\end{array}$ \\
\hline 2003 dummy & $\mathrm{N} / \mathrm{A}$ & N/A & $\mathrm{N} / \mathrm{A}$ & $\mathrm{N} / \mathrm{A}$ & N/A & $\mathrm{N} / \mathrm{A}$ & $\begin{array}{l}.26^{* * *} \\
(.06)\end{array}$ & $\begin{array}{l}.03 \\
(.03)\end{array}$ \\
\hline $\mathrm{N}$ & 4,649 & 374 & 5,073 & 449 & 5,236 & 503 & 6,303 & 667 \\
\hline Pseudo R2 & .13 & .12 & .11 & .08 & .10 & .11 & & .09 \\
\hline Log Likelihood & $-1,130$ & & $-1,356$ & & $-1,486$ & & $-2,955$ & \\
\hline
\end{tabular}

- Each specification also includes the independent variables from Table A3.

- Heteroskedastic-robust standard errors are in parentheses.

- * Coefficient statistically significant at $10 \% \quad * *$ at $5 \% \quad * * * \quad$ at $1 \%$ 